\title{
Layering in seedling production of rambutan
}

\section{Renata Aparecida de Andrade ${ }^{1,}$, , Samir Paulo Jasper², Amanda Garcia Bagatim, Guilherme Nacata ${ }^{1}$}

\author{
${ }^{1}$ Departamento de Produção Vegetal, Faculdade de Ciências Agrárias e Veterinárias/UNESP, Jaboticabal, Brazil \\ ${ }^{2}$ Faculdades Integradas de Bauru, Bauru, Brazil
}

\section{Email address:}

reandrad@fcav.unesp.br(R. A. de Andrade), samir@agronomo.eng.br(S. P. Jasper), amanda_cr.aveiro@hotmail.com(A. G. Bagatim), guilherme_nacata@hotmail.com(G. Nacata)

\section{To cite this article:}

Renata Aparecida de Andrade, Samir Paulo Jasper, Amanda Garcia Bagatim, Guilherme Nacata. Layering in Seedling Production of Rambutan. Plant. Vol. 1, No. 5, 2013, pp. 50-53. doi: 10.11648/j.plant.20130105.11

\begin{abstract}
The rambutan fruit is a culture that still little known, but with high potential of market, such as lychee, fruit of the same family. The orchards have been installed using seedlings originated from seeds, generating high variability among the plants and produced fruits. As the layering has been shown effective to obtaining the litchi seedlings, this research was realized, in order to verify the response of rambutan propagation by layering in the different seasons of the year (spring, summer, autumn and winter). The branches were selected from the middle of the canopy of the trees in production, and about $50 \mathrm{~cm}$ from the top was done the girdling, which was wrapped with sphagnum and transparent plastic. For each season, were done 12 air layering in 5 plants, totaling 60 air layering. The evaluation, realized 110 days after layering, as about: percentage of air layering root, callus, and survival of the layers while in the matrix plant. From the results, can be conclude that is possible to produce seedlings of rambutan culture by layering, indicating that be done in the spring.
\end{abstract}

Keywords: Nephelium Lappaceum L., Propagation, Rooting, Season

\section{Introduction}

The culture of fruits is an area in constant growth, due to investment by producers or by the population, which have increasingly sought a healthy diet, in addition to fruits yet unknown, and this has contributed greatly to the expansion of the exotic fruits. Among this fruits, can be find the rambutan (Nephelium lappaceum L.).

Although still little known by the general population, the rambutan has a high potential of market, how occurred with the lychee (Litchi chinensis Sonn.), fruit of the same family, that was unknown at the beginning and the market price was high, not providing consumption by the large majority of the population, but now is widespread among different social classes, with great evolution as the market and production area.

The rambutan belongs to the family Sapindaceae, originally from Malaysia, is becoming one of the most important tropical fruit grown in Asia (1). The major producer in Brazil is the Bahia state (region of Itabuna/Ilhéus) and the largest consumer market are the São Paulo state, where some producers installed orchards from this culture using seedlings originated from seeds, with high variability and without information about the regional response. In the states of Bahia and Pará, the rambutan is cultivated with excellent production performance and fruit quality $(2,3)$.

In 2010, according to data obtained from the CEAGESP (4), the states of Bahia and Pará put the product (fruits of rambutan) on the market in the period between February and August (20.22 tons), with a higher offer during the months of May, June and July (5.54, 11.04 and 2.247 tons, respectively), being the state of Bahia responsible for almost all of this offering, with little participation of Pará in May (0.50 tons). The state of São Paulo has provided for market in the period from September to January (1.25 tons), with the highest amounts observed in January (1.19 tons).

These data allows observing the high potential of São Paulo for the production and marketing of this fruit, especially by the fact to providing the product to the market in times of short supply by Bahia. Is very important, however, realize research, principally with the objective to known the characteristics of the culture, in order to permit an appropriate management, observing the development in São Paulo state, and the most appropriate method to obtaining the seedlings, since these have a great importance in the formation and installation of the orchards.

The biggest consumption of this fruit is "in nature" form, 
but also can be used to make jellies, jams, and the seeds can be roasted for consumption as brown. The consumer demand for fresh fruit looks for a good aspect, being the size and the color important factors. The aryl, edible portion of the fruit, must constitute a high proportion of the total weight of the fruit, separating easily from seed, have good flavor and texture (1).

The propagation methods used for rambutan are seeds, grafting and layering. Seed propagation is relatively easy, but the plants come into production about 8-10 years after the field planting, presenting variability among the plants $(5,6)$, while the plants originated from vegetative propagation produce in 3-4 years and the result is an uniform orchard $(7,8)$. Due to the presence of different types of flowers, which necessitates the occurrence of cross-pollination, is essential a vegetative propagation, being the layering a recommended practice (9).

The layering is a process where occurs the rooting of branches still attached to the matrix plant, showing how advantage the earlier of first production when compared to plants produced sexually. It is, however, a fairly laborious system, being the seedlings yield from each matrix plant down, resulting in higher price. The rooting rate is mainly influenced by the variety and season of the year (10), and the period most appropriate for the implementation of air layering is from spring until the last of the summer, when the metabolic functions of the plant are in full activity, making to occurs a great synthesis and storage of important carbohydrates in the formation of the roots (11).

The genetic variability among the species and the cultivars of the fruit trees, in the process of root formation, is very great. Due to this, some species and cultivars have major facility in the process of rooting, while others need more care (12), as well as some species have satisfactory responses when propagated by layering, while for others, the best response is obtained by the method of cutting.

Given the above, and considering that the layering has been a great method and has been widely used for propagation of lychee, fruit of the same family of the rambutan, this research was realized to verify the possibility of using the layering also for the production of seedlings of rambutan, observing the response of the plants in the different seasons of the year (spring, summer, autumn and winter).

\section{Material and Methods}

The experiment was realized with adult plants of rambutan, in a commercial orchard, located in Taquaritinga city, São Paulo state, Brazil, with coordinates $21^{\circ} 26^{\prime} 45.5^{\prime \prime}$ south latitude and 48 $37^{\prime} 57.4^{\prime \prime}$ west longitude, with an altitude of $493 \mathrm{~m}$. By the International System of Köeppen, the climate is Aw, characterized to be rainy tropical dry winters.

The layering was realized in the different seasons of the year: spring (month of September), summer (January), autumn (April) and winter (July). The branches were selected from the middle of the canopy of trees in full production, and about $50 \mathrm{~cm}$ from the top was done the girdling, that were wrapped with dampened sphagnum and transparent plastic. For each season, were made 12 air layering in 5 plants (each plant functioning as a repetition), totaling 60 air layering. The evaluation, realized 110 days after layering, as about: percentage of air layering root, callus, and survival of the layers while in the matrix plant.

The experimental design was in a randomized block, being the data transformed into arc sine $\sqrt{ }(\mathrm{x} / 100)$, subjected to analysis of variance and comparison of means by Tukey test $(\alpha=0.05)$, with the statistical program SigmaPlot (2008) [13].

\section{Results and Discussion}

There was no significant difference in percentage of rooting and callus formation, as shown in the Table 1. However, did not occurred the same for the survival percentage, which had higher rates for air layering when done in the spring, autumn and winter, without difference among them, though differing from the rate observed when the layering was realized in the summer. Although did not occurred difference in the statistical analysis, can be noted very clear that the rooting percentage was higher in the spring.

Table 1. Results of the statistical analysis for percentage of survival, rooting and callus formation with the use of the air layering to produce seedlings of rambutan. Jaboticabal city, São Paulo state, Brazil. 2013

\begin{tabular}{cccc}
\hline $\begin{array}{c}\text { Epoch of the year } \\
\text { (EY) }\end{array}$ & $\begin{array}{c}\text { Survival } \\
(\%)\end{array}$ & $\begin{array}{c}\text { Rooting } \\
(\%)\end{array}$ & $\begin{array}{c}\text { Callus } \\
(\%)\end{array}$ \\
\hline Spring & $90.00 \mathrm{~A}$ & 63.00 & 22.82 \\
Summer & $42.60 \mathrm{~B}$ & 36.77 & 37.54 \\
Autumn & $90.00 \mathrm{~A}$ & 39.71 & 42.99 \\
Winter & $83.29 \mathrm{~A}$ & 26.18 & 59.01 \\
TEST F & & & \\
EY & $11.540 * *$ & $1.499 \mathrm{NS}$ & $1.763 \mathrm{NS}$ \\
CV (\%) & 19.62 & 68.44 & 62.00 \\
\hline
\end{tabular}

In each column, for each factor, means followed by the same capital letter do not differ among themselves by "Tukey test," the 5\% probability. NS: not significant $(\mathrm{P}<0.05) *$ : Significant $(\mathrm{P}<0.05) * *$ : Significant $(\mathrm{P}<0.01)$. $\mathrm{CV} \%$ : Coefficient of variation.

The difference about the epoch of the year when the air layering was realized in the rambutan, in respect to cell division, can be found by observing the Figure 1, which records the volume of roots developed in the branches. It follows that, as higher the root volume for a given seedling, better will be the establishment in nursery. Thus, even without statistical difference for this variable, the response of the plant allows to distinguish between the seasons of the year, which is most suitable for the crop in question.

The opposite of the verified in this research for the percentage of rooting was reported by authors when, evaluating the influence of the epoch of realization of layering in Japanese quince, verify that only had significant difference for percentage of rooting, being the highest rates 
observed in July (winter) [14].
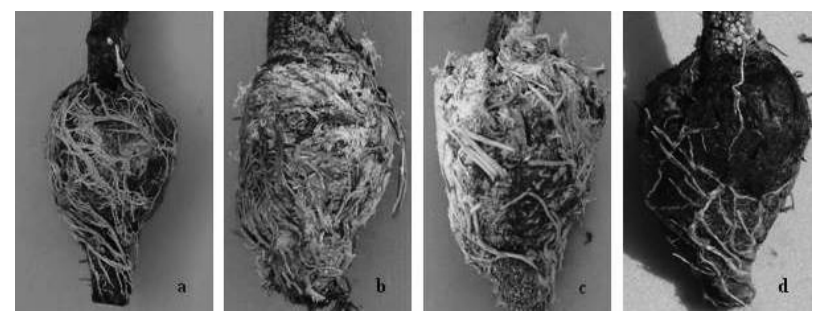

Figure 1. Root appearance of air layering of rambutan in the spring (a), summer (b), autumn (c) and winter (d). Jaboticabal city, São Paulo state Brazil. 2013

In this research, the rooting percentage was higher in the spring, which was to be expected, since this epoch of the year have elevated temperature and humidity, factors that promote the cell division, the production of assimilates and hormones that induce the root formation. So, according to related in literature for the most of species, the layering should be taken in the spring or late summer, corresponding to the growth stage of the plants, occurring carbohydrate accumulation and other substances important for the emission of roots [15], being the same also observed for jaboticaba tree [16] and for cashew [17].

The process of root formation is influenced for a large number of factors, that may act alone or together, among which may be mentioned physiological conditions and age of the matrix plant, juvenility, and environmental factors, such as water availability, light and substrate, which may explain the lower rate of rooting in summer when compared to spring, because has too high temperatures, contributing to the excessive transpiration of the plant, requiring greater amount of water, and it is not always available at this time of the year [11]. The lowest rates of rooting observed for autumn and winter are also due to climatic factors associated with physiological state of the plant, and can be explained by the fact to occur competition between leaves and roots for carbohydrate [18].

The coefficient of variation obtained for the percentage of rooting in this research should be due to the different stages of development of the branches, showing that, despite the attempt to homogenize them, each part of the plant has a different response, depending of the physiology of the plant [19].

\section{Conclusions}

From the results obtained in this research, can be concluded that there is possible to produce seedlings of rambutan by air layering, and can be indicate that is better to realize the procedure in the spring.

\section{Acknowledgements}

To FAPESP, for the concession of the research support to realization of the project (Process number 2011/20034-1).

\section{References}

[1] Tindall, H.D. Rambutan cultivation. FAO Plant Production and Protection Food and Agriculture Organization of the United Nation, Paper 121. (1994)

[2] Sacramento, C.K., Luna, J.V.U. Potencial do cultivo do rambutão na Região Sul da Bahia. Bahia Agrícola. 6:3 (2004) 24-26.

[3] Sacramento, C.K., Luna, J.V.U., Muller, C.H., Carvalho, J.E.U., Nascimento, W.M.O. Rambotã, in: Janay Almeida dos Santos-Serejo, Jorge Luis Loyola Dantas, Clovis Vaz Sampaio, Ygor da Silva Coelho. (Eds.), Fruticultura Tropical- Espécies Nativas e Exóticas, Brasília, 2009.

[4] CEAGESP - Companhia de Entrepostos e Armazéns Gerais de São Paulo - Sistema de Informação de Mercado, São Paulo: Seção de Economia e Desenvolvimento, não publicado (2011).

[5] Andrade, R.A., Wickert, E., Martins, A.B.G., Andrade, M.M.C., Lemos, E.G.M. Diversidade genética de acessos de Nephelium lappaceum L. através de caracterização morfológica e molecular. Comunicata Scientiae. 2:2 (2011) 91-99.

[6] Andrade, R.A., Lemos, E.G.M., Martins, A.B.G., Paula, R.C. Caracterização morfológica de plantas de rambutan. Acta Scientiarum Agronomy. 31:4 (2009) 613-619.

[7] Valmayor, R.V., Mendoza JR, D.B., Aycardo, H.B., Palencia, C.O. Growth and flowering habits, floral biology and yield of rambutan (Nephelium lappaceum Linn.). Philippines Agriculture. 54 (1970) 359-374.

[8] Meletti, L.M.M., Teixeira, L.A.J. Propagação de plantas, in: Meletti, L.M.M. (Ed.), Propagação de frutíferas tropicais, Guaíba, 2000.

[9] Morton, J. Rambutan: Fruits of warm climates, Miami, Florida, 1987.

[10] Kanwar, J.S., Kalhon, G.S. Propagation studies in litchi (Litchi chinensis Sonn.). Journal of Research Punjab Agricultural University. 23:1 (1986) 33-39.

[11] Hartmann, H.T., Kester, D.E., Davies JR, F.T., Geneve, R.L. Plant propagation: principles and practices, New Jersey, 2002.

[12] Couvillon, G.A. Rooting responses to different treatments. Acta Horticulturae. 227 (1988) 187-196.

[13] SIGMAPLOT (2008). For windows, version 11.0. Systat Software.

[14] Pio, R., Dall'orto, F.A.C., Alvarenga, A.A., Abrahão, E., Chagas, E.A., Signorini, G. Propagação do marmeleiro japonês por estaquia e alporquia realizadas em diferentes épocas. Ciência e Agrotecnologia. 31:2 (2007) 570-574.

[15] Fachinello, J.C., Hoffmann, A., Nachtigal, J.C. Propagação de plantas frutíferas, Brasília, 2005.

[16] Danner, M.A., Citadin, I., Fernandes JR, A.A., Assmann, P., Mazaro, S.M., Donazzolo, J., Sasso, S.A.Z. Enraizamento de jabuticabeira (Plinia trunciflora) por mergulhia aérea. Revista Brasileira de Fruticultura. 28:3 (2006) 530-532. 
[17] Nagabhushanam, S. Vegetative propagation in cashew Review of work done at vital. Acta Horticulturae. 108 (1985) $59-65$.

[18] Davison, R.M. The physiology of the kiwifruit vine, in:Warrington LJ, Weston C (ed). Kiwifruit science and management, New Zealand, 1990.

[19] SIMÃO, S. Tratado de fruticultura, Piracicaba, Brasil, 1998 